\title{
T regulatory cell markers in oral squamous cell carcinoma: Relationship with survival and tumor aggressiveness
}

\author{
GEANE MOREIRA $^{1}$, LÍVIA BONFIM FULGÊNCIO ${ }^{1}$, ELISMAURO FRANCISCO DE MENDONÇA ${ }^{2,3}$, \\ CLÁUDIO RODRIGUES LELES ${ }^{3}$, ALINE CARVALHO BATISTA ${ }^{3}$ and TARCÍLIA APARECIDA DA SILVA ${ }^{1}$ \\ ${ }^{1}$ Department of Oral Surgery and Pathology, Dental School, Federal University of Minas Gerais, \\ Belo Horizonte; ${ }^{2}$ Head and Neck Division of Araújo Jorge Hospital, Association of Cancer Combat of Goiás; \\ ${ }^{3}$ Department of Oral Medicine (Oral Pathology), Dental School, Federal University of Goiás, Goiânia, Brazil
}

Received February 13, 2009; Accepted August 4, 2009

DOI: 10.3892/ol_00000023

\begin{abstract}
Tumor-infiltrating lymphocytes (TILs) are a heterogeneous cell family which plays an important role in tumorassociated immune response. Of these, T regulatory (Treg) cells have also been shown to inhibit anti-tumor response. We aimed to evaluate the expression of $\mathrm{T}$ regulatory cell markers (CD4, CD25, CTLA-4 and FoxP3) in samples of oral cavity squamous cell carcinoma (OCSCC) and lip SCC (LSCC) by immunohistochemistry. The relationship of Treg markers with survival data and the proliferative index were also evaluated. We observed similar numbers of CD4-, CD25- and FoxP3+ cells in OCSCC and LSCC. On the other hand, numbers of CTLA-4+ cells were significantly lower in OCSCC than in LSCC. OCSCC samples with high numbers of CD4 exhibited a high proliferative index, while samples with high CTLA-4 counts demonstrated a low tumoral proliferative index. A log-rank test showed that patients with OCSCC that presented high counts of CD4 showed a significantly decreased survival compared with patients with low cell counts. In contrast, high $\mathrm{CD} 25^{+}$cell counts were associated with increased survival. Our results suggest an association of CD4 with poor prognosis, while CD25 expression is related with favorable prognosis. These findings result from the heterogeneity of TIL subsets that display an antagonistic role in tumor immune cell response.
\end{abstract}

\section{Introduction}

Immune-inflammatory cell response in the tumor microenvironment is regulated by a heterogeneous family of tumor infiltrating lymphocytes (TILs), which may have a dual function

Correspondence to: Dr Tarcília Aparecida da Silva, Departamento de Clínica, Patologia e Cirurgia Odontológicas, Faculdade de Odontologia, Universidade Federal de Minas Gerais, Av. Antônio Carlos 6627, CEP 31.270-901, Belo Horizonte, Minas Gerais, Brazil E-mail: tarcilia@ufmg.br

Key words: squamous cell carcinoma, $\mathrm{T}$ regulatory cells, immune response of inhibiting or promoting tumor growth and progression $(1,2)$. Many reasons account for the failure of host immune systems to control tumor growth, such as the development of tumor variants that escape immune recognition or down-regulation of the major histocompatibility complex class molecules. The latter involve immune suppression mediated by $\mathrm{T}$ regulatory (Treg) cells and other cells of the innate immune system with suppressor activities (3-7).

Treg cells comprise $5-10 \%$ of the total population of $\mathrm{CD}^{+}$ $\mathrm{T}$ cells in mice and men and were primarily thought to be critically involved in the repression of autoimmune disorders (3-7). Treg cells are characterized by the constitutive expression of a transmembrane protein, CD25 (the $\alpha$-chain of the receptor for interleukin-2), cytotoxic T lymphocyte antigen-4 (CTLA-4) and forkhead transcription factor (FoxP3) (3-9).

Previous results showed that Treg cells are potent inhibitors of anti-tumor immune response and are associated with poor prognosis in different types of cancer $(6,10-23)$. The depletion of $\mathrm{CD} 4{ }^{+} \mathrm{CD} 25^{+}$Treg cells has been shown to result in a slower tumor growth rate (13). A high prevalence of Treg cells has been observed in the stroma of the pancreatic ductal adenocarcinoma. These cells have also been closely correlated with several malignant features, such as distant metastasis, high tumor grade and advanced pathological tumor-nodemetastasis stage (18). Significant numbers of regulatory $\mathrm{T}$ cells increase in the peripheral blood of patients suffering from squamous cell carcinoma (SCC) of the head and neck $(12,24,25)$. In contrast, a recent study showed a longer survival and better locoregional control in patients with high numbers of tumor-infiltrating CD25+ cells in head and neck SCC (26).

CTLA-4 is a member of the immunoglobulin superfamily and binds to the B7.1 and B7.2 costimulatory molecules (3-8). The CTLA-4 gene encodes a receptor that is transiently expressed on activated $\mathrm{T}$ cells and plays a pivotal role in immune regulation by providing a negative feedback signal to the $\mathrm{T}$ cell once an immune response has been initiated and completed (8). CTLA-4 plays a role in the suppressive activity of CD4 and CD25 Treg against CD4 or CD8 T cells $(6,8)$. Specific antibodies that block CTLA-4 have been used as anti-tumor agents, resulting in the enhancement of the anti-tumor immune response $(10,11,14,16,20,21)$. On the other 
Table I. Antibodies and protocol of immunohistochemical reaction.

\begin{tabular}{|c|c|c|c|}
\hline Antibody (clone) & Dilution & Antigen retrieval & Secondary antibody \\
\hline Anti-CD4" (0.N.52) & $1: 100$ & EDTA buffer (pH 8.0 for $30 \mathrm{~min}$ at $98^{\circ} \mathrm{C}$ ) & EnVision \\
\hline Anti-CD25 (N-19) & $1: 50$ & EDTA buffer (pH 8.0 for $30 \min$ at $\left.98^{\circ} \mathrm{C}\right)$ & EnVision \\
\hline Anti-CTLA-4a (C-19) & $1: 1200$ & Citrate buffer (pH 6.0 for $30 \mathrm{~min}$ at $\left.95^{\circ} \mathrm{C}\right)$ & Kit-LSAB \\
\hline Anti-FoxP3a (236A/E7) & $1: 400$ & Citrate buffer (pH 6.0 for $30 \mathrm{~min}$ at $\left.95^{\circ} \mathrm{C}\right)$ & Kit-LSAB \\
\hline $\mathrm{Ki}^{\mathrm{b}}$ (MM1) & $1: 100$ & Citrate buffer (pH 6.0 for $30 \mathrm{~min}$ at $\left.95^{\circ} \mathrm{C}\right)$ & Kit-LSAB \\
\hline
\end{tabular}

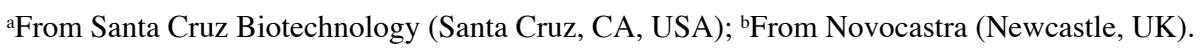

hand, CTLA-4 was previously demonstrated to play a role in the destruction of tumor cells in vivo (27).

FoxP3 expression has been thought to be the most specific marker of Treg cells. This protein is a member of the forkhead family of transcription factors that are critically involved in the development and function of $\mathrm{CD}_{2} 5^{+}$regulatory $\mathrm{T}$ cells $(7,9,28,29)$. In human cancer, FoxP3 expression is usually correlated with an unfavorable course of disease and may even represent an independent prognostic variable in terms of overall and progression-free survival (15-18,23). In contrast, FoxP $3^{+} \mathrm{CD}^{+} \mathrm{T}$ cells were demonstrated to positively correlate with locoregional control in head and neck cancer (30).

The significance of Treg cell markers in oral squamous cell carcinoma (OSCC) and lip squamous cell carcinoma (LSCC) has yet to be determined. This study aimed to investigate the expression of CD4, CD25, CTLA-4 and FoxP3 in oral cavity (OC)SCC and LSCC and their relationship with tumor aggressiveness and prognosis.

\section{Materials and methods}

Patient population. Surgically excised specimens of primary OCSCC were obtained from the files of the Anatomopathology and Cytopathology Division of Araujo Jorge Hospital, Association of Cancer Combat of Goias. The study was approved by the Ethics Committee of the Universidade Federal de Minas Gerais and Araujo Jorge Hospital.

Our patient population consisted of 18 patients with primary OCSCC, of which 7 were without cervical lymph node metastasis and 11 presented cervical lymph node metastasis. Eight other patients had LSCC. Patients with oral cavity tumors were submitted to surgical treatment consisting of cervical lymph node removal with microscopic evaluation. However, no patient with oral cavity or lip tumors received radiotherapy, chemotherapy or any other treatment prior to surgery. Clinical data (gender, age, ethnic group, tobacco and alcohol consumption, tumor location, extension, $\mathrm{T}$ and $\mathrm{N}$ stages) and follow-up information (clinical outcome and survival time) were obtained from medical records. Specimens were fixed in $10 \%$ buffered formalin ( $\mathrm{pH}$ 7.4) and were paraffin embedded. The microscopic features were evaluated from the analysis of one $5 \mu \mathrm{m}$ section of each sample, stained routinely with hematoxylin and eosin. The sections were examined by light microscopy to confirm the presence or absence of lymph node metastasis, and to characterize OCSCC.
Immunohistochemistry. Sections $(3 \mu \mathrm{m})$ from routinely processed paraffin-embedded blocks were deparafinized and dehydrated. Dewaxed sections were subjected to antigen retrieval (Table I). Endogenous peroxidase was blocked by incubation with 3\% hydrogen peroxide and methanol (1:1). The slides were then incubated with the primary antibodies indicated in Table I for $18 \mathrm{~h}$ at $4^{\circ} \mathrm{C}$. After washing in TBS, the sections were treated with the EnVision ${ }^{\circledR}+$ Dual Link System-HRP (Dako, Carpinteria, CA, USA) or $\mathrm{LSAB}^{\circledR}+$ system, HRP Peroxidase Kit (Dako). The sections were then incubated in 3,3'-diaminobenzidine (DAB; Dako) for 2-5 min. The sections were stained with Mayer's hematoxylin and then covered. Negative controls were obtained by the omission of primary antibodies, which were substituted by $1 \%$ PBS-BSA and by non-immune rabbit (X0902; Dako) or mouse (X501-1; Dako) serum.

Cell counting and statistical analysis. In primary OCSCC (lip and oral cavity) samples, the densities of CD4, CD25, CTLA-4 and FoxP3 cells were determined in relation to the total of inflammatory infiltrate adjacent to the tumor front. To establish the proliferative tumor index, the number of cells showing Ki67 staining was evaluated as a proportion of the total epithelial cell population, but only the OCSCC samples were considered. Counts were performed in 15 alternate microscopic high power fields using an integration graticule (4740680000000-Netzmikrometer x12.5, Carl Zeiss, Göttingen, Germany). $\mathrm{P}<0.05$ was considered to be statistically significant. Comparative analyses between experimental groups were performed using the non-parametric KruskalWallis, followed by Dunn and/or Mann-Whitney tests.

The influence of tumor-associated Treg markers on the prognosis of OCSCC patients was evaluated by the Kaplan-Meier. CD4, CD25, CTLA-4 and FoxP3 values were dichotomized by the median, and differences in survival between groups were evaluated by the log-rank test. Survival time was calculated from surgical resection until the last follow-up appointment of the patient or until the patient succumbed to the disease. Significance was set at 0.05 .

\section{Results}

The main clinical features of our series of 18 patients with OCSCC and 8 patients with LSCC are summarized in Table II. In OCSCC and LSCC, CD4 ${ }^{+}, \mathrm{CD} 25^{+}, \mathrm{CTLA}-4^{+}$ 
Table II. Main clinical findings of patients with OCSCC (oral cavity and lip).

\begin{tabular}{|c|c|c|}
\hline Clinical features & OCSCC $(\%)$ & $\operatorname{LSCC}(\%)$ \\
\hline \multicolumn{3}{|l|}{ Age } \\
\hline$\leq 60$ years & 39.00 & 37.5 \\
\hline$>60$ years & 61.00 & 62.5 \\
\hline \multicolumn{3}{|l|}{ Gender } \\
\hline Male & 61.00 & 87.5 \\
\hline Female & 39.00 & 12.5 \\
\hline \multicolumn{3}{|l|}{ Ethnic group } \\
\hline Caucasian & 55.50 & 62.5 \\
\hline Non-caucasian & 44.50 & 37.5 \\
\hline \multicolumn{3}{|l|}{ Location } \\
\hline Tongue & 44.00 & 0 \\
\hline Floor of the mouth & 28.00 & 0 \\
\hline Superior lip & 0 & 25.0 \\
\hline Inferior lip & 0 & 75.0 \\
\hline Others & 28.00 & 0 \\
\hline \multicolumn{3}{|l|}{ Tobacco } \\
\hline Yes & 93.75 & 85.7 \\
\hline \multicolumn{3}{|l|}{ Alcohol } \\
\hline Yes & 56.25 & 50.0 \\
\hline \multicolumn{3}{|l|}{ T stage } \\
\hline $\mathrm{T} 2$ & 0 & 62.5 \\
\hline T3-T4 & 100.0 & 37.5 \\
\hline \multicolumn{3}{|l|}{ Clinical outcome } \\
\hline Dead & 44.50 & 0 \\
\hline Alive (overall survival) & $22.62 \pm 16.52$ & $69.0 \pm 43.5$ \\
\hline \multicolumn{3}{|l|}{ Survival time } \\
\hline$\geq 48$ months & 0 & 75.0 \\
\hline$<48$ months & 100.0 & 25.0 \\
\hline
\end{tabular}
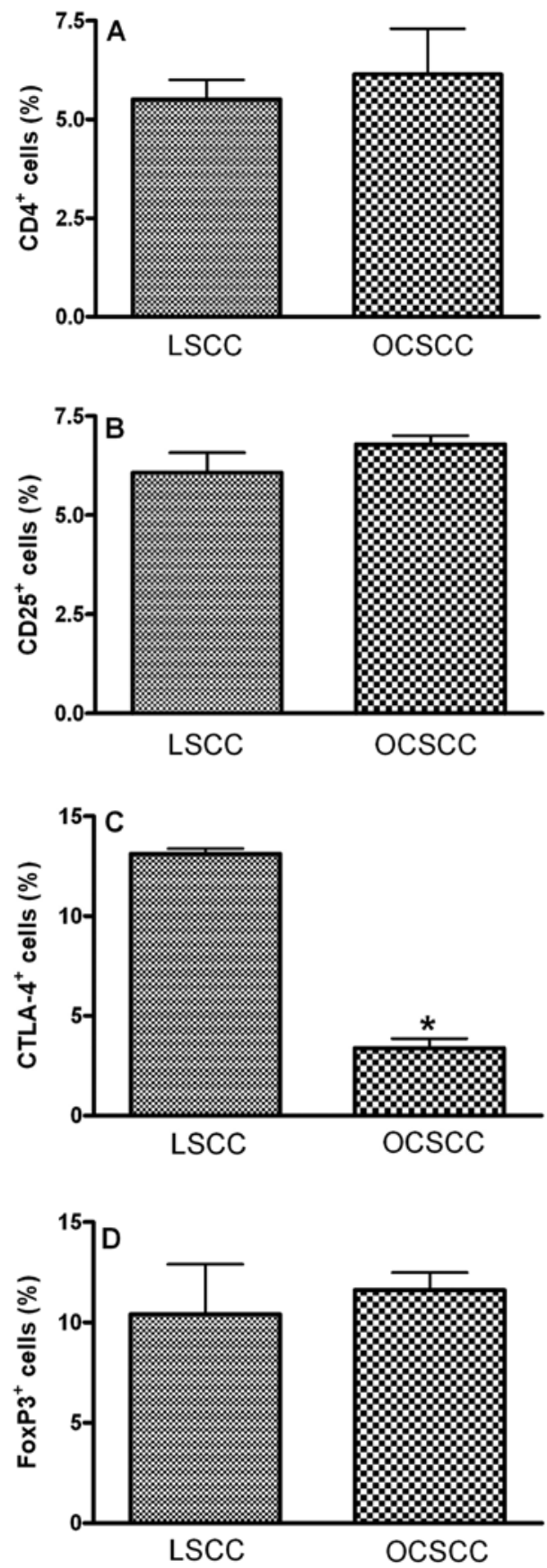

Figure 1. Densities of (A) $\mathrm{CD}^{+}$, (B) $\mathrm{CD}^{2} 5^{+}$, (C) $\mathrm{CTLA}_{-} 4^{+}$and (D) $\mathrm{FoxP}^{+}$ cells in primary oral cavity squamous cell carcinoma (OCSCC) $(n=18)$ and lip squamous cell carcinoma (LSCC) $(n=8)$. The percentage of positive cells was calculated as the proportion of the total of inflammatory cells. Results are expressed as the mean of positive cells \pm SD. *Indicates a significant difference, when comparing metastatic OCSCC and LSCC, $\mathrm{P}<0.05$. $\mathrm{P}=0.826)$ (Fig. 1A), CD25- $(6.08 \pm 0.50$ and $6.79 \pm 0.22$ for LSCC and OCSCC, respectively; $\mathrm{P}=0.159$ ) (Fig. 1B) and FoxP3- (10.41 \pm 2.48 and $11.61 \pm 0.88$ for LSCC and OCSCC, respectively; $\mathrm{P}=0.586$ ) (Fig. 1D) positive cells in OCSCC and LSCC, respectively. On the other hand, a lower percentage of CTLA- $4^{+}$cells was observed in OCSCC $(3.39 \pm 0.46)$ compared with LSCC (13.12 \pm 0.26$)(\mathrm{P}=0.007$; Fig. 1C).

To analyze the relationship of Treg cell markers and the proliferative index of tumoral cells in OCSCC, the values were dichotomized into high and low CD4, CD25, CTLA-4 and FoxP3 groups by using the median values. Samples with high counts of CD4 showed significantly more Ki67-positive cells $(\mathrm{P}<0.05$; Fig. 2A). In contrast, samples with high counts of CTLA-4 exhibited significantly diminished proliferative indices $(\mathrm{P}<0.05$; Fig. $2 \mathrm{C})$. No significant association between the proliferative index and $\mathrm{CD}_{2} 5^{+}$(Fig. 2B) and FoxP3 ${ }^{+}$ (Fig. 2D) populations was achieved.

With regard to the last follow-up, the mean survival time was 43.8 months (95\% CI, 23.7-64) for patients with OCSCC without lymph node metastasis and 34.5 months (95\% CI, 17.551.5) for patients with OCSCC with lymph node metastasis. The mean follow-up was 49.75 months (95\% CI, 37.61-61.89) for patients with LSCC. For survival analysis, only patients 

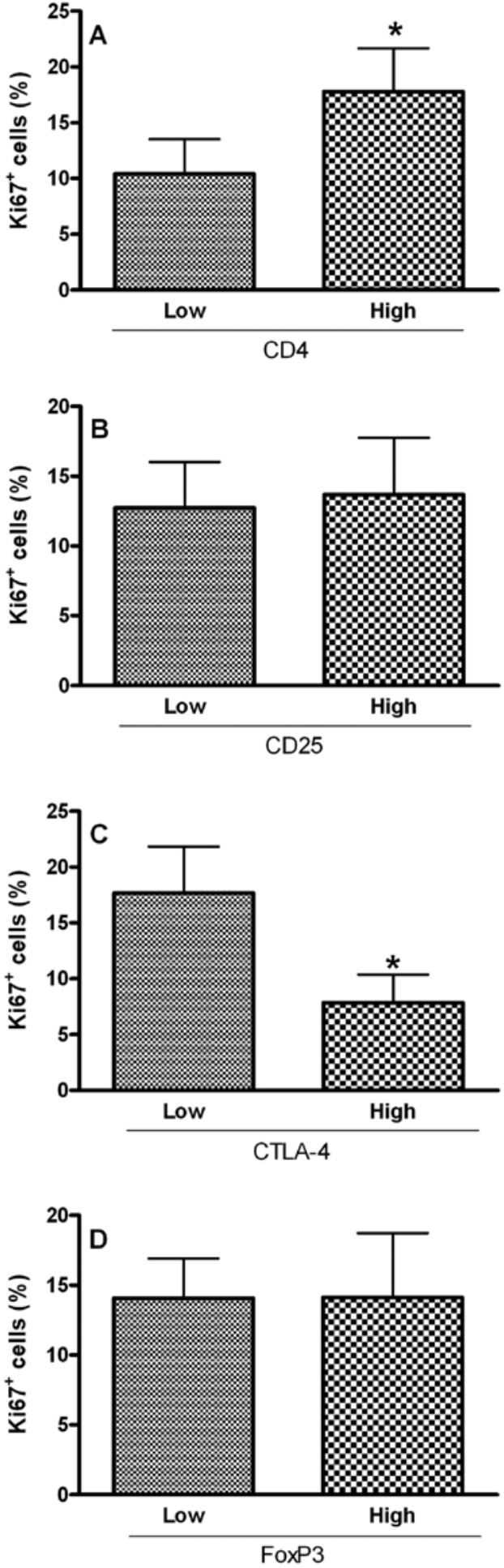

Figure 2. Relationship between the proliferative index and densities of (A) CD4, (B) CD25, (C) CTLA-4 and (D) FoxP3 in OCSCC ( $n=18)$. The values of CD4, CD25, CTLA-4 and FoxP3 were dichotomized into high and low groups using the median values. The proliferative index of the tumor was determined by evaluating the number of cells showing Ki67 staining as a proportion of the total epithelial cell population. The results are expressed as the mean of positive cells \pm SD. *Indicates a significant difference, when comparing high and low groups; $\mathrm{P}<0.05$.

with OCSCC were considered; a log-rank test showed no difference in survival between the high and low CTLA-4 and FoxP3 groups. However, patients with low counts of CD4+ cells
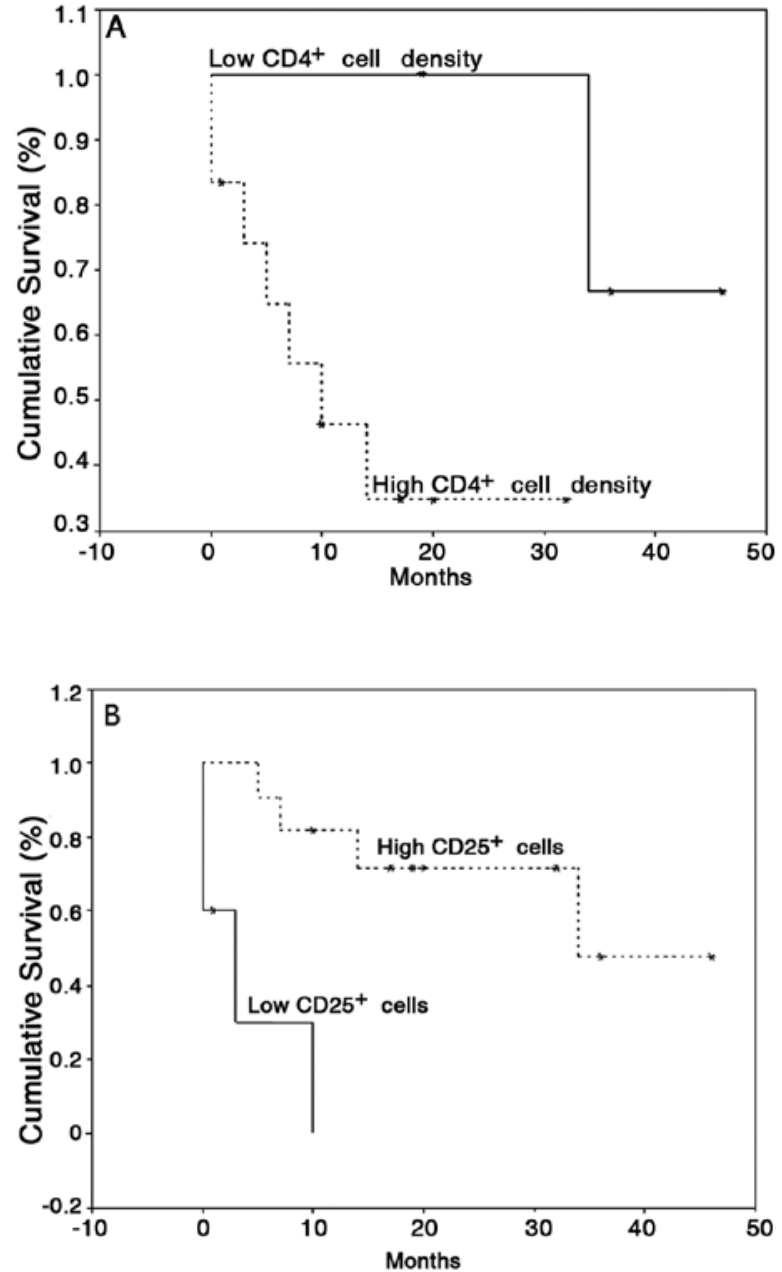

Figure 3. Kaplan-Meier survival curves according to the density status of (A) CD4 and (B) CD25 in primary OCSCC. CD4+ and CD25+ cell numbers were dichotomized by median values (high groups, $n=9$; low groups, $n=9$ ).

showed a significant increase in survival ( $42 \pm 3$ months) compared with patients with high $\mathrm{CD} 4{ }^{+}$cell counts $(15 \pm 4$ months) $(\mathrm{P}=0.05$; Fig. $3 \mathrm{~A})$. Furthermore, patients with low counts of $\mathrm{CD} 25^{+}$cells showed a significantly lower survival ( $4 \pm 2$ months) compared with patients with high $\mathrm{CD} 25^{+}$counts ( $33 \pm 5$ months) $(\mathrm{P}=0.0008$; Fig. 3B).

\section{Discussion}

Innate and adaptive immunity play important roles in immunosurveillance and tumor destruction. Both types of effector responses are regulated by a heterogeneous family of TILs. TILs are present in the earlier stages of head and neck SCC with the relative proportion of $\mathrm{CD}^{+} \mathrm{CD}^{+}$being higher than or equal to $\mathrm{CD}^{+} \mathrm{CD}^{+}(31)$. $\mathrm{CD} 4{ }^{+} \mathrm{T}$ cells play a central role in initiating and maintaining anticancer immune responses (30). However, regulatory $\mathrm{CD} 4{ }^{+} \mathrm{CD} 25^{+} \mathrm{T}$ cells that express FoxP3 have also been shown to inhibit anti-tumor effector $\mathrm{T}$ cells (3-7) and may, therefore, contribute to the growth of human tumors $(6,10-23)$. An increase in Treg cell populations has been observed in different types of cancers, such as pancreas (18), ovarian tumors (17), metastatic melanoma (23) and head and neck cancer $(12,24,25)$. 
It has been reported that LSCC patients usually have a favorable prognosis, and a low rate of regional lymph node metastasis and mortality when compared with OCSCC $(32,33)$. Thus, the LSCC group was included in this study as a model of non-metastatic and low aggressive SCC. Notably, we found a similar percentage of $\mathrm{CD}^{-}, \mathrm{CD}^{2} 5^{-}$and $\mathrm{FoxP}^{+}$cells in OCSCC and LSCC. In contrast, a diminished percentage of CTLA- $4^{+}$cells was observed in OCSCC compared with LSCC. In addition, a higher CTLA-4 expression was significantly associated with a low tumor proliferative index. These results may be related to the previously demonstrated function of CTLA-4 in the destruction of tumor cells in vivo via interaction with B7 (27). On the other hand, much evidence indicates the importance of the CTLA-4 blockade in the prevention of malignancy and the spread of metastases $(10,11,14,16,20,21)$. Moreover, in OSCC, the A/A polymorphism of the CTLA-4 gene, which results in a high producer phenotype, is associated with poor survival (34). We found no association between CTLA-4 expression and survival. These discrepancies may be due to the significant variation in the clinical outcome and methodologies used in the different studies. Furthermore, the expression of CTLA-4 appears not to be exclusive to Treg cells and may be associated with anti-tumor effector cells $(3,6,8)$.

The current model suggests that epithelial tumor cells recruit Tregs to inhibit anti-tumor immunity in the tumor microenvironment, thereby limiting the efficiency of anti-tumor immune responses (35). On the other hand, regulatory FoxP3 ${ }^{+} \mathrm{CD} 4^{+}$ $\mathrm{T}$ cells are positively correlated with locoregional control in head and neck SCC (30). A possible explanation is that Treg down-regulates the harmful inflammatory reaction, which favors tumor progression. Furthermore, higher Treg numbers in lymphomas predict improved survival and prognosis of patients (35). We observed that high numbers of $\mathrm{CD} 25^{+}$cells are positively correlated with survival. In accordance, Loose et al verified a trend towards longer survival and better locoregional control in patients with a high level of tumor-infiltrating $\mathrm{CD} 25^{+}$cells (26). It is important to consider that the CD4 $\mathrm{CD} 25^{+}$phenotype does not discriminate between activated and regulatory T cells. A significantly higher frequency of doublepositive $\mathrm{CD} 25^{+} \mathrm{FoxP}^{+}$cells has recently been observed in OCSCC in relation to control lymphoepithelial tissue, but no association between these cells and clinical parameters was verified (36).

The clinical significance of $\mathrm{CD}^{+} \mathrm{T}$ cells inside tumors is controversial. A large number of tumor-infiltrating $\mathrm{CD} 4^{+}$cells was found to be an independent favorable prognostic factor in esophageal squamous cell carcinomas (37). On the other hand, an increased level of tumor-infiltrating $\mathrm{CD}^{+}{ }^{+}$cells is associated with poor outcome in renal cell carcinoma (38). In the present study, patients with low counts of $\mathrm{CD} 4^{+}$cells presented a significantly increased survival in relation to patients with high $\mathrm{CD}^{+}{ }^{+}$cell counts. In accordance, samples with an elevated $\mathrm{CD}^{+}$cell percentage exhibited a high tumor proliferative index. Our results suggest a regulatory/suppressive role for these cells in OCSCC as previously shown (39). However, considering the heterogeneity of the $\mathrm{CD} 4^{+} \mathrm{T}$ cell phenotype, a further definition of the role of these subsets in OCSCC (using double or triple staining), as well as subsequent confirmation of activity in vitro is needed.
FoxP3 expression is correlated with the development and function of Treg. FoxP3 is a member of the forkhead family of transcription factors that are critically involved in the development and function of $\mathrm{CD} 25^{+}$regulatory $\mathrm{T}$ cells $(7,9,29)$. The expression of FoxP3 can be transiently induced in human nonTreg cells by activation through the T-cell receptor $(28,29)$. FoxP3 expression was thought to be restricted to the T-cell lineage, but recently FoxP3 expression was detected in melanoma (40) and other types of tumor cells (41). We did not, however, verify FoxP3 expression in neoplastic epithelial cells. FoxP3 expression can be influenced by different cytokines such as TGF- $\beta$, IL-10 or IL-2 (7,9,29). Notably, a slight increase in IL-10 concomitant with FoxP3 expression was observed in OCSCC samples (data not shown).

In conclusion, our results suggest an association of CD4 expression with poor prognosis, while CD25 expression is related to a favorable prognosis of OCSCC. These findings may result from the heterogeneity of TIL subsets that display antagonistic and complex roles in tumor immune cell response.

\section{Acknowledgements}

The authors thank the Anatomopathology and Cytopathology Division of the Araujo Jorge Hospital and the Association of Cancer Combat of Goias, Goiânia, Brazil. This work was supported by grants from the Conselho Nacional de Desenvolvimento Científico e Tecnológico (CNPq) (grants 401305/2005-8 and 471878/2006-5). T.A.S. is a research fellow of CNPq.

\section{References}

1. Hanahan D, Lanzavecchia A and Mihich E: Fourteenth Annual Pezcoller Symposium: the novel dichotomy of immune interactions with tumors. Cancer Res 63: 3005-3008, 2003.

2. Oliveira-Neto HH, Leite AF, Costa NL, et al: Decrease in mast cells in oral squamous cell carcinoma: possible failure in the migration of these cells. Oral Oncol 43: 484-490, 2007.

3. Akbar AN, Taams LS, Salmon M and Vukmanovic-Stejic M: The peripheral generation of $\mathrm{CD} 4^{+} \mathrm{CD} 25^{+}$regulatory $\mathrm{T}$ cells. Immunology 109: 319-325, 2003.

4. Wang HY, Lee DA, Peng G, et al: Tumor-specific human CD4+ regulatory $\mathrm{T}$ cells and their ligands: implications for immunotherapy. Immunity 20: 107-118, 2004.

5. Wei WZ, Morris GP and Kong YC: Anti-tumor immunity and autoimmunity: a balancing act of regulatory $\mathrm{T}$ cells. Cancer Immunol Immunother 53: 73-78, 2004.

6. Wang RF: Regulatory $\mathrm{T}$ cells and innate immune regulation in tumor immunity. Springer Semin Immunopathol 28: 17-23, 2006.

7. Yamaguchi $\mathrm{T}$ and Sakaguchi S: Regulatory $\mathrm{T}$ cells in immune surveillance and treatment of cancer. Semin Cancer Biol 16: 115-123, 2006.

8. Chen L: Co-inhibitory molecules of the B7-CD28 family in the control of T-cell immunity. Nat Rev Immunol 4: 336-347, 2004.

9. Chen W, Jen W, Hardegen $\mathrm{N}$, et al: Conversion of peripheral $\mathrm{CD} 4{ }^{+} \mathrm{CD} 25$ naive $\mathrm{T}$ cells to $\mathrm{CD} 4{ }^{+} \mathrm{CD} 25^{+}$regulatory $\mathrm{T}$ cells by TGF- $\beta$ induction of transcription factor FoxP3. J Exp Med 198: 1875-1886, 2003.

10. Hurwitz AA, Yu TF, Leach DR and Allison JP: CTLA-4 blockade synergizes with tumor-derived granulocyte-macrophage colonystimulating factor for treatment of an experimental mammary carcinoma. Proc Natl Acad Sci USA 95: 10067-10071, 1998.

11. Hurwitz AA, Foster BA, Kwon ED, et al: Combination immunotherapy of primary prostate cancer in a transgenic mouse model using CTLA-4 blockade. Cancer Res 60: 2444-2448, 2000. 
12. Tartour E, Mosseri V, Jouffroy T, et al: Serum soluble interleukin-2 receptor concentrations as an independent prognostic marker in head and neck cancer. Lancet 357: 1263-1264, 2001.

13. Jones E, Dahm-Vicker M, Simon AK, et al: Depletion of CD25+ regulatory cells results in suppression of melanoma growth and induction of autoreactivity in mice. Cancer Immun 2: 1-12, 2002.

14. Phan GQ, Yang JC, Sherry RM, et al: Cancer regression and autoimmunity induced by cytotoxic T lymphocyte-associated antigen 4 blockade in patients with metastatic melanoma. Proc Natl Acad Sci USA 100: 8372-8377, 2003.

15. Curiel TJ, Coukos G, Zou L, et al: Specific recruitment of regulatory $\mathrm{T}$ cells in ovarian carcinoma fosters immune privilege and predicts reduced survival. Nat Med 10: 942-949, 2004.

16. Ghaderi A, Yeganeh F, Kalantari T, et al: Cytotoxic T lymphocyte antigen-4 gene in breast cancer. Breast Cancer Res Treat 86: 1-7, 2004.

17. Wolf D, Wolf AM, Rumpold H, et al: The expression of the regulatory $\mathrm{T}$ cell-specific forkhead box transcription factor FoxP3 is associated with poor prognosis in ovarian cancer. Clin Cancer Res 11: 8326-8331, 2005.

18. Hiraoka N, Onozato K, Kosuge T and Hirohashi S: Prevalence of $\mathrm{FoxP}^{+}$regulatory $\mathrm{T}$ cells increases during the progression of pancreatic ductal adenocarcinoma and its premalignant lesions. Clin Cancer Res 12: 5423-5434, 2006.

19. Larkin J, Tangney M, Collins C, et al: Oral immune tolerance mediated by suppressor T cells may be responsible for the poorer prognosis of foregut cancers. Med Hypotheses 66: 541-544, 2006.

20. Downey SG, Klapper JA, Smith FO, et al: Prognostic factors related to clinical response in patients with metastatic melanoma treated by CTL-associated antigen- 4 blockade. Clin Cancer Res 13: 6681-6688, 2007.

21. Fecci PE, Ochiai H, Mitchell DA, et al: Systemic CTLA-4 blockade ameliorates glioma-induced changes to the $\mathrm{CD}^{+} \mathrm{T}$ cell compartment without affecting regulatory $\mathrm{T}$-cell function. Clin Cancer Res 13: 2158-2167, 2007.

22. Fu J, Xu D, Liu Z, et al: Increased regulatory $\mathrm{T}$ cells correlate with CD8 T-cell impairment and poor survival in hepatocellular carcinoma patients. Gastroenterology 132: 2328-2339, 2007.

23. Miracco C, Mourmouras V, Biagioli M, et al: Utility of tumourinfiltrating $\mathrm{CD}_{25}{ }^{+}$FoxP3 $^{+}$regulatory $\mathrm{T}$ cell evaluation in predicting local recurrence in vertical growth phase cutaneous melanoma. Oncol Rep 18: 1115-1122, 2007.

24. Strauss L, Bergmann C and Whiteside TL: Functional and phenotypic characteristics of D4 ${ }^{+}$CD25-high FoxP3 ${ }^{+}$Treg clones obtained from peripheral blood of patients with cancer. Int $\mathrm{J}$ Cancer 121: 2473-2483, 2007.

25. Chikamatsu K, Sakakura K, Whiteside TL and Furuya N: Relationships between regulatory $\mathrm{T}$ cells and $\mathrm{CD}^{+}$effector populations in patients with squamous cell carcinoma of the head and neck. Head Neck 29: 120-127, 2007.
26. Loose D, Signore A, Bonanno E, et al: Prognostic value of CD25 expression on lymphocytes and tumor cells in squamous-cell carcinoma of the head and neck. Cancer Biother Radiopharm 23: 25-33, 2008.

27. Bai XF, Liu J, May KF Jr, Guo Y, Zheng P and Liu Y: B7-CTLA4 interaction promotes cognate destruction of tumor cells by cytotoxic T lymphocytes in vivo. Blood 99: 2880-2889, 2002.

28. Wang J, Ioan-Facsinay A, van der Voort EI, Huizinga TW and Toes RE: Transient expression of FoxP3 in human activated nonregulatory CD4+ T cells. Eur J Immunol 37: 129-138, 2007.

29. Zheng Y and Rudensky AY: Foxp3 in control of the regulatory T cell lineage. Nat Immunol 8: 457-462, 2007.

30. Badoual C, Hans S, Rodriguez J, et al: Prognostic value of tumorinfiltrating $\mathrm{CD}^{+}{ }^{+} \mathrm{T}$-cell subpopulations in head and neck cancers. Clin Cancer Res 12: 465-472, 2006.

31. Böheim K, Denz H, Böheim C, Glassl H and Huber H: An immunohistologic study of the distribution and status of activation of head and neck tumor infiltrating leukocytes. Arch Otorhinolaryngol 244: 127-132, 1987.

32. Antunes JLF, Biazevic MGH, de Araujo ME, Tomita NE, Chinellato LEM and Narvai PC: Trends and spatial distribution of oral cancer mortality in São Paulo, Brazil, 1980-1998. Oral Oncol 37: 345-350, 2001.

33. Vartanian JG, Carvalho AL, Filho MJA, Júnior MH, Magrin J and Kowalski LP: Predictive factors and distribution of lymph node metastasis in lip cancer patients and their implications on the treatment of the neck. Oral Oncol 40: 223-227, 2004.

34. Wong YK, Chang KW, Cheng CY and Liu CJ: Association of CTLA-4 gene polymorphism with oral squamous cell carcinoma. J Oral Pathol Med 35: 51-54, 2006.

35. Ke X, Wang J, Li L, Chen IH, Wang H and Yang XF: Roles of $\mathrm{CD}^{+}{ }^{+} \mathrm{XCD} 25$ (high) FoxP3 ${ }^{+}$Tregs in lymphomas and tumors are complex. Front Biosci 13: 3986-4001, 2008.

36. Schwarz S, Butz M, Morsczeck C, Reichert TE and Driemel O: Increased number of CD25 FoxP3 regulatory $\mathrm{T}$ cells in oral squamous cell carcinomas detected by chromogenic immunohistochemical double staining. J Oral Pathol Med 37: 485-489, 2008.

37. Cho Y, Miyamoto M, Kato K, et al: $\mathrm{CD}^{+}$and $\mathrm{CD}^{+} \mathrm{T}$ cells cooperate to improve prognosis of patients with esophageal squamous cell carcinoma. Cancer Res 63: 1555-1559, 2003.

38. Bromwich EJ, McArdle PA, Canna K, et al: The relationship between T-lymphocyte infiltration, stage, tumour grade and survival in patients undergoing curative surgery for renal cell cancer. Br J Cancer 89: 1906-1908, 2003.

39. Agarwal A, Rani M, Saha GK, et al: Disregulated expression of the Th2 cytokine gene in patients with intraoral squamous cell carcinoma. Immunol Invest 32: 17-30, 2003.

40. Ebert LM, Tan BS, Browning J, et al: The regulatory $\mathrm{T}$ cellassociated transcription factor FoxP3 is expressed by tumor cells. Cancer Res 68: 3001-3009, 2008.

41. Karanikas V, Speletas M, Zamanakou M, et al: FoxP3 expression in human cancer cells. J Transl Med 6: 19-24, 2008. 